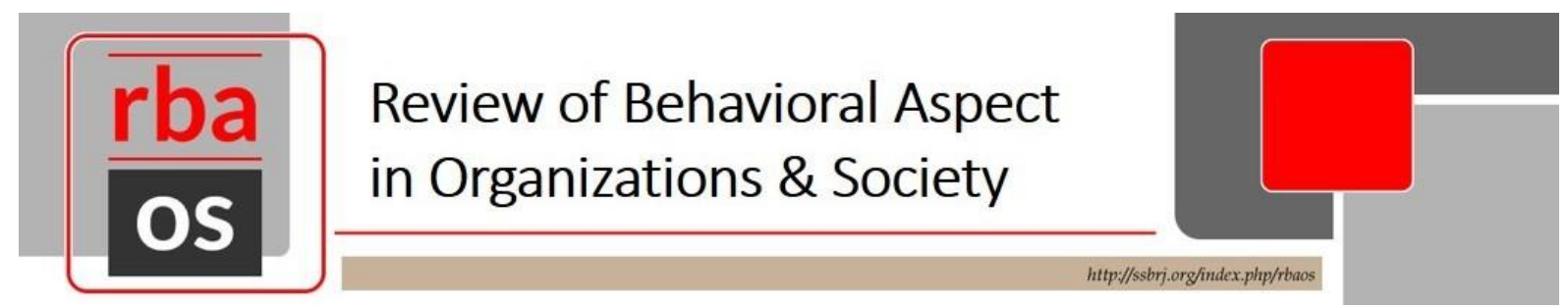

\title{
PROPERTY SALES TAX AND BUYING INTEREST IN INDONESIA
}

\author{
Vierly Ananta Upa, Universitas Pelita Harapan Kampus Surabaya, Indonesia \\ Frandy E.F. Karundeng, Universitas Pelita Harapan Kampus Surabaya, Indonesia
}

\begin{abstract}
The Surabaya city government still applies the old rules, which do not implement a reduction in property sales tax rates. Data from the Office of Revenue and Financial Management (DPPK) The Surabaya city government noted, in 2015, the revenue from property sales tax reached $\mathrm{Rp} 825$ billion. This is the reason behind the Surabaya city government's refusal to reduce property sales tax rates. Based on this, we want to examine whether the policies taken by the Surabaya government to not reduce property sales tax rates can affect the interest of the purchasing power of the people of Surabaya. The population in this study were all people residing in the city of Surabaya. The data collection technique carried out by the researcher was a purposive sampling technique. In this study, researchers used questionnaires as data collection techniques. The results showed that the decision of the Surabaya city government to reject the decline in property sales tax rates did not affect the people's buying interest in property in Surabaya.
\end{abstract}

Keywords: property, buying, tax 


\section{Introduction}

Initially, property sales tax collection in Indonesia was the authority of the central government. However, in 2011, the tax collection was transferred to the regional government. This is regulated in Act No. 28 of 2008 concerning Regional Taxes and Regional Levies. Through the Act, the management of property sales tax is submitted and becomes the full authority of each district/city. Changes in property sales taxes to local taxes have the potential to increase Regional Original Revenue and aim to increase district and city local taxing power. The results of the property sales tax collection were distributed $20 \%$ for the central government and $80 \%$ for the regional government.

According to Jati (2016), the Surabaya city government still applies the old rules, which do not implement a reduction in property sales tax rates. Data from the Office of Revenue and Financial Management (DPPK) The Surabaya city government noted, in 2015, the revenue from property sales tax reached Rp 825 billion. Tax incentives can cause potential losses in tax revenue (Dong, 2018). This is the reason behind the Surabaya city government's refusal to reduce property sales tax rates. Based on this, we want to examine whether the policies taken by the Surabaya government to not reduce property sales tax rates can affect the interest of the purchasing power of the people of Surabaya. This study aims to determine and analyze the impact of the decision of the Surabaya city government to refuse property sales tax on the interest in buying property in Surabaya.

In this study, two variables were used, namely property purchase interest and property sales tax. The indicators of the property sales tax variable are tariffs, tax base, and when owed. Whereas according to Rizky (2014) which is an indicator of the variable buying interest of a prospective customer is Attention, which is the attention of prospective consumers of products offered by producers; Interest, interest in prospective consumers of products offered by producers; Desire, the desire of prospective consumers to have products offered by producers; and Action, namely prospective customers make purchases of the products offered. This research is expected to be a reference for similar research. In addition, this research is also expected to provide a general picture for the government regarding the impact of the decline in property sales tax rates on people's buying interest in property.

\section{Literature Review}

\section{Principle of Tax Collection}

The principle of taxation has been designed by some experts. The principles of taxation, as proposed by Adam Smith in his book "An Inquiry into the Nature and Cause of the Wealth of Nations" states that taxation should be based on several principles. Including Principles of Equality, Principles of Certainty, Principles of Convenience (timely tax collection), and Principles of Efficiency.

The Principle of Equality (principle of balance with the ability or the principle of justice) is a principle that revealed that the tax collection by the government should be in accordance with the capabilities and income of the taxpayer. The government may not discriminate against a taxpayer. While the principle of Certainty (principle of legal certainty) is a principle that revealed that all taxation should be based on the regulation so that those who violate the law will be sanctioned. The principle Convenience of Payment (principle of timely taxation process or principle of convenience) is a principle that revealed that the tax should be collected at the right time for taxpayers (the best time), for example when new taxpayer receives income or when the taxpayer receives a gift. The Principle of Efficiency (principle of 
efficient or economic principle) is a principle that revealed that the cost of tax collection process should be conducted as efficiently as possible. Do not let the cost of tax collection is greater than the sum of tax collected. (Suandy, 2006).

\section{Taxable Property}

According to Lewis (2003), not all land parcels and buildings that could be taxed are taxed. Some otherwise taxable properties are exempt by law. Exempted properties, according to current law, comprise: (1) those used in the operation of certain not-for-profit religious, social, health and/or education activities; (2) cemeteries and the like; (3) wildlife reserves, national parks and forests and other similar protected areas; (4) those pertaining to official foreign diplomatic presence; and (5) those related to the functioning of certain international organizations. The identification of taxable properties is based on 'self-discovery' principles. Taxpayers are legally responsible for providing all relevant data regarding properties to the tax office

\section{Tax Billing and Collection}

According to Lewis (2003), responsibility for tax billing and collection is, officially at least, divided between central and local governments. The central government's deconcentrated property tax office typically prints and sends a notification of taxes due (surat pemberitahuan pajak terutang-SPPT) to each taxpayer in its region and an indication of where the tax should be paid, typically a near-by branch of a state bank. In some areas of the country, especially the urban and rural sectors, the tax bill is hand-delivered by the local government. Local governments are also in charge of following up on tax collection in urban and rural sectors after billing has been carried out. Central government tax offices are responsible for property tax collection follow-up in the estates, forestry, and mining sectors.

\section{Property Purchase Interest}

Property means property owned by someone. The property market in Indonesia is still quite extensive, where, based on statistical data, there are still approximately $20 \%$ of families who do not have a home, and it will continue to increase along with the growth in birth rates and population migration in an area. As the second-largest city in Indonesia, the Surabaya property market continues to grow and develop, this is due to the continued improvement in the economic conditions in East Java, in addition to an increase in the property business in Surabaya and East Java also began to be felt since the turmoil of the crisis in Europe and the US. People began to save their property by buying property, and that helped to drive up property prices there. When buying a house consumers will be faced with many considerations such as housing prices which of course must be adjusted to their purchasing power, the location of how easy access and direction of development of the area later, the type and availability of facilities, quality of buildings, environmental conditions, home design and many more another consideration. The desire to buy/purchase interest is a strong impulse generated in a person after witnessing, hearing or reading messages to buy or use the products offered (Kasali, 1992). Specifically it says that desires/interests are part of the components forming attitudes. In the theory of attitude, there is a theory that explains the relationship between buying interest with actual purchases, the Theory of Reasoned Action Model by I. Ajzen, and M. Fishbein (1980). One's buying interest is formed from 2 factors namely attitudes, and subjective norms.

1. Attitude, is one of the concepts used by marketers in understanding consumers, where the most important component in attitude is behavior.

2. Subjective Norms are social influences that a person gets when taking action or decision, for example family, relatives or friends 


\section{Hypothesis}

Based on the background and literature review that has been done before, the hypothesis can be formulated as follows:

H1: There is a significant effect of property sales tax on interest in buying property

\section{Research Method}

Population and Sample

According to Arikunto (2010), the population is the whole subject of research. The population in this study were all people residing in the city of Surabaya. The number of samples used in this study was 200. The data collection technique carried out by the researcher was a purposive sampling technique with the following criteria:

1. Residents who are domiciled in Surabaya

2. Have or will buy a house

3. Have or will make a payment for property sales tax

\section{Data Collection}

Methods (methods or techniques) designate an abstract word and are not embodied in objects, but can only be seen using questionnaires, interviews, observations, examinations, documentation, and others. In this study, researchers used questionnaire methods or questionnaires as data collection techniques. The questionnaire method according to Arikunto (2010), is a written statement used to obtain information from respondents in the sense of personal reports or things he knows. Sugiyono (2012) argues that questionnaires or questionnaires are data collection techniques carried out by giving a set of questions or written statements to respondents to answer.

\section{Data Analysis}

The research model is a simple regression. The independent variable is property sales tax (PST). The dependent variable is buying interest (BI). The model used in this study is as follows:

Where:

$$
\mathrm{BI}=\mathrm{a}+\mathrm{b} 1 \mathrm{PST}
$$

BI = Buying interest

PST = Property sales tax

Data analysis conducted in the study using SPSS by examining the effect of property sales tax with interest in buying a property.

\section{Result and Discussion}

Respondent Profile

This questionnaire was distributed to 200 respondents. The respondents consisted of 152 males and 48 females in which 20-30 years old were 15\%, 31-40 years were 36\%, 41-50 years were $27 \%, 51-60$ were $20 \%$, and more than 60 years was $2 \%$. The respondent's profession consisted of $46 \%$ entrepreneurs, $13 \%$ civil servants, $32 \%$ employees (32\%), and $9 \%$ other professions.

\section{Descriptive Statistics}

Descriptive statistics in this study serve to describe or give an overview of the object under study through sample or population data as they are without doing analysis and making general conclusions (Sugiyono, 2012). This descriptive statistical analysis uses class intervals. The following are the descriptive statistics: 
Table 1. Descriptive Statistics

\begin{tabular}{lrrrr}
\hline & N & Minimum & Maximum & \multicolumn{1}{c}{ Mean } \\
\hline IB & 200 & 1 & 5 & $3.4825^{*}$ \\
PST & 200 & 1 & 5 & $3.63^{*}$ \\
\hline$*$ denote significance at $5 \%$, levels (two-tailed test).
\end{tabular}

The table above shows the average value of each item statement with interest in buying interest and property sales tax. The average statement related to the variable buying interest illustrates the interest of the public to buy a property after the government's decision to refuse to reduce property sales tax. The results of testing descriptive statistics on interest variables indicate the medium category. This illustrates that there are some people who discourage them from buying property after the government's decision to reject the decline in property sales tax rates. However, some people also continue to purchase property even though there is no decrease in property sales tax rates.

In addition, the table above also shows the average value of each item statement with a property sales tax variable. The average statement related to the property sales tax variable describes the public opinion regarding the government's decision to refuse to reduce property sales tax. The results of testing descriptive statistics on the property sales tax variable indicate the medium category. This illustrates that some people agree, and some of them do not agree with the government's decision to reject the decline in property sales tax.

\section{Adjusted $R^{2}$ and $t$-test}

The coefficient of determination has a function to explain the extent to which the ability of the independent variable (property sales tax) on the dependent variable (buying interest). The following are the results of testing the coefficient of determination.

Table 2. Coefficient of Determination

\begin{tabular}{lrrrr}
\hline Model & $\mathrm{R}$ & $\mathrm{R}$ square & Adj. R square & Std. Error of the Estimate \\
\hline 1 & .252 & .063 & .056 & 7.902 \\
\hline
\end{tabular}

Test the correlation coefficient (Adj $\mathrm{R}^{2}$ ) between the property sales tax variable $(\mathrm{X})$ with the purchase interest variable $(\mathrm{Y})$ obtained at 0.056. This shows that the property sales tax variable is able to influence the variables of property purchase interest by $5.6 \%$.

Hypothesis testing is done to determine whether there is an influence of independent variables with the dependent variable partially. Following are the results of hypothesis testing:

Table 3. T-test

\begin{tabular}{lrrrrr}
\hline Model & \multicolumn{1}{c}{ B } & Std. Error & Beta & \multicolumn{1}{l}{ T } & \multicolumn{1}{l}{ Sig } \\
\hline (Constant) & 42.911 & 3.900 & & 11.003 & .000 \\
IB_PST & .415 & .141 & .252 & 2.944 & .006 \\
\hline
\end{tabular}

Hypothesis test results show a p-value (Sig) of 0.006. This means that there is no influence of property sales tax on buying interest. This condition indicates that the refusal to decrease property sales tax rates can not affect people's buying interest in property.

\section{Discussion}

The decision of the Surabaya city government to reject the decline in property sales tax affected the people's buying interest. The rejection of the decline in property sales tax 
occurred because the Surabaya city government was wary of a decline in regional income.

Based on the results of the questionnaire distributed to respondents, most respondents were neutral. The results of descriptive statistics show that the average value of each item statement on property sales tax variables and buying interest is in the medium category. This shows that the responses of most respondents regarding property sales tax get a neutral response. This condition shows that property sales tax does not have a significant effect on their buying interest. This is in line with the results of testing the hypothesis which shows that property sales tax does not affect buying interest. The reason behind the respondents' responses is still neutral, and the property sales tax does not affect because now the economy is experiencing sluggishness, which has an impact on buying interest in property. This condition makes respondents hesitant to buy property at this time.

In addition, the current property sales tax rate is $5 \%$. This tariff is considered not too significant for the community when compared to taxes and other fees that must be paid when purchasing property, for example, value-added tax, notary fees, and other costs. These costs can reach a minimum of $10 \%$ of the property price.

According to Sudarma and Darmayasa (2018), individual behaviour is influenced by individual intention (behaviour intention), intention is influenced by attitude, subjective norm, and perceived behaviour control. Behaviour control perceived is interpreted by the degree of control performed by the tax authorities. Nevertheless, the implementation of taxpayers' compliance on social and religious societies cannot afford to only take the economic deterrence approach; it takes a combination of approaches by integrating the locality philosophical values.

\section{Conclusion and Implication}

Based on the results of the research discussed earlier, we can conclude that the decision of the Surabaya city government to reject the decline in property sales tax rates did not affect the people's buying interest in a property in Surabaya. This condition is shown from the results of the descriptive statistics that describe the responses of respondents tend to be neutral, and the results of hypothesis testing, which shows the property sales tax do not significantly influence buying interest.

The results of this study provide an overview of the Government of Indonesia that property sales tax does not affect buying interest from the public. There are still many other factors that can affect buying interest in property. Thus the decision of the central government to reduce property sales tax to increase interest in buying property has not been effective. For the Surabaya government the decision to refuse to lower property taxes is the right decision. Based on the results of this study, people's interest in buying property is not only influenced by property sales tax, but there are other things that influence someone to buy property. Also, it is expected that further researchers can examine other factors that can influence buying interest in property.

\section{References}

Arikunto, S. (2010). Research Procedure: A Practical Approach. Jakarta: Rineka Cipta.

Dispendukcapil. (2016). Surabaya City Population Statistics. Retrieved January, 5, 2019 from Dispendukcapil database on the World Wide Web: http://dispendukcapil.surabaya.go.id/stat_new/index.php 
Dong, Yue. (2018). The impact of double tax treaties on inward FDI in ASEAN countries. Journal of Business and Finance in Emerging Markets, 1(2), 128-152.

Jati, Y. (2016). WP Not paying taxes, Surabaya will lose 29.5 billion. Retrieved January 25, 2019 from Okezone sites on the World Wide Web: http://finansial.bisnis.com/ $\mathrm{read} / 20160302 / 10 / 524525 / \mathrm{wp}$-pribadi-tak-bayar-pajak-surabaya-terancamkehilangan-rp295-m

Lewis, B. D. (2003). Property tax in Indonesia: measuring and explaining administrative (under-) performance. Public Administration and Development, 23(3), 227-239.

Perda. (2010). Land and building tax. Perda Surabaya.

Rizky, M. F. (2014). Effect of Promotion and price on buying interest in Obama housing. Retrieved January 27, 2019 from Universitas Muhammadiyah Sumatera Utara sites on the World Wide Web: http://jurnal.umsu.ac.id/index.php/mbisnis/ article/ download/ 182/pdf_37.

Suandy, E. (2006). Taxation. Second Edition. Jakarta: Salemba Empat.

Sudarma, I Made, and I Nyoman Darmayasa. (2018). The philosophy of Tat Twam Asi: The foundation of consciousness regarding post-tax amnesty (Cases in Indonesia). Journal of Business and Finance in Emerging Markets, 1(2), 153-160.

Sugiyono. (2012). Quantitative, Qualitative, and $R \& D$ Research Methods. Bandung: Alfabeta. 
